International Business and Global Economy 2018, no. 37, pp. 168-182

Biznes międzynarodowy w gospodarce globalnej 2018, nr 37, s. 168-182

Edited by the Institute of International Business, University of Gdańsk

ISSN 2300-6102

e-ISSN 2353-9496

DOI 10.4467/23539496IB.18.012.9385

Iwona Szczepaniak

Instytut Ekonomiki Rolnictwa i Gospodarki Żywnościowej -

Państwowy Instytut Badawczy

\title{
Ocena bezpieczeństwa żywnościowego i samowystarczalności żywnościowej Polski na tle państw Unii Europejskiej
}

Celem artykułu jest ocena bezpieczeństwa żywnościowego Polski na tle państw Unii Europejskiej. W analizie wykorzystano Światowy Indeks Bezpieczeństwa Żywnościowego, który pozwala ustalić poziom bezpieczeństwa żywnościowego poszczególnych państw, z uwzględnieniem: dostępności żywności, dostępu do żywności oraz jakości i bezpieczeństwa żywności. Odrębnie oceniono zasoby naturalne i zdolność dostosowania sektora rolnictwa do zmian tych zasobów. Umożliwiło to przyjrzenie się uwarunkowaniom zapewnienia bezpieczeństwa żywnościowego poszczególnych krajów. Dodatkowo zaprezentowano mocne i słabe strony bezpieczeństwa żywnościowego Polski. Ponieważ jednym ze wskaźników zapewnienia bezpieczeństwa żywnościowego pod względem dostępności żywności na poziomie krajowym jest samowystarczalność żywnościowa, $\mathrm{w}$ artykule zaprezentowano także jej analizę $\mathrm{w}$ zakresie wybranych produktów rolno-spożywczych w Polsce na tle pozostałych państw UE. W analizie tej wykorzystano dane FAO. Przedstawione w artykule zagadnienia ukazują Unię Europejską jako związek zapewniający bezpieczeństwo żywnościowe na poziomie całego ugrupowania, ale jednocześnie świadczą o dużym zróżnicowaniu sytuacji między poszczególnymi państwami.

Słowa kluczowe: bezpieczeństwo żywnościowe, samowystarczalność żywnościowa, Polska, Unia Europejska

Klasyfikacja JEL: Q13, Q17, Q18

\section{Assessment of food security and food self-sufficiency of Poland as compared to other European Union countries}

The aim of the paper is to assess Poland's food security as compared to selected European Union countries. The analysis used the Global Food Security Index, which allows to determine the level of food security in individual countries, including: food affordability, food availability, food quality, and food safety. The assessment of natural resources and resilience was conducted separately. This made it possible to look at the determinants of food security in individual countries. In addition, the strengths and challenges of Poland's food security have been presented. Since one of the indicators of ensuring food security in terms of food availability at the national level is selfsufficiency, the paper also presents an analysis of food self-sufficiency in selected agri-food products of Poland in comparison with other EU member states. FAO data was used in the analysis. 
The issues presented in the article show that the EU as a whole ensures food security; however, there are significant differences between individual countries.

Keywords: food security, food self-sufficiency, Poland, European Union

JEL classification: Q13, Q17, Q18

\section{Wprowadzenie}

Żywność jest dla człowieka najważniejszym dobrem, posiadającym wartości odżywcze, dzięki którym jego organizm utrzymuje się przy życiu i może się prawidłowo rozwijać [Kowalczyk, 2016, s. 9]. Zgodnie z art. 3 Powszechnej Deklaracji Praw Człowieka „każdy człowiek ma prawo do życia, wolności i bezpieczeństwa swej osoby" [ONZ, 1948], a zatem również do żywności. Z tego też względu zapewnienie bezpieczeństwa żywnościowego jako elementu bezpieczeństwa narodowego staje się obecnie, wraz z rozwojem procesów globalizacji, coraz większym i bardziej złożonym wyzwaniem.

Mimo wzrostu gospodarczego i wprowadzenia różnych systemów ograniczających występowanie niedożywienia, problem ten jest wciąż aktualny także w krajach rozwiniętych. W 2016 r. 79 mln obywateli Unii Europejskiej żyło poniżej progu ubóstwa, a 16 mln było zależnych od pomocy żywnościowej organizacji charytatywnych. Dodatkowo na zapewnienie bezpieczeństwa żywnościowego niekorzystnie wpływało coraz częściej występujące zjawisko nadkonsumpcji [Obiedzińska, 2016, s. 126].

Cel niniejszego artykułu stanowi ocena, które z państw członkowskich Unii Europejskiej (z akcentem położonym na Polskę) są najbardziej, a które najmniej narażone na brak bezpieczeństwa żywnościowego. Ponieważ jednym ze wskaźników bezpieczeństwa żywnościowego pod względem dostępności żywności na poziomie krajowym jest samowystarczalność żywnościowa, w artykule zaprezentowano także analizę samowystarczalności żywnościowej w zakresie wybranych produktów rolno-spożywczych Polski na tle pozostałych państw członkowskich UE.

\section{Bezpieczeństwo żywnościowe}

\subsection{Uwagi teoretyczne}

Bezpieczeństwo żywnościowe (food security) jest pojęciem wieloaspektowym, które obejmuje aspekty gospodarcze, polityczne, demograficzne, społeczne, kulturowe oraz techniczne [European Commission, 2009, s. 7]. Najogólniej rzecz biorąc, o bezpieczeństwie żywnościowym można mówić w sytuacji, kiedy wszyscy ludzie, 
cały czas, mają fizyczny, społeczny i ekonomiczny dostęp do wystarczającej, bezpiecznej i odżywczej żywności, która zaspokaja ich potrzeby żywieniowe i preferencje wynikające z prowadzenia aktywnego i zdrowego trybu życia [FAO, 2009, s. 8; FAO, 2015, s. 53]. Na podstawie tej definicji można zidentyfikować cztery wzajemnie powiązane ze sobą wymiary bezpieczeństwa żywnościowego, takie jak [European Commission, 2009, s. 7-8]:

- fizyczna dostępność żywności (availability of food) - wystarczająca dla wszystkich ilość żywności wyprodukowanej w kraju, pochodzącej z importu oraz oferowanej w ramach pomocy żywnościowej, a także przez odpowiednie lokalne i krajowe polityki prowadzone w zakresie wyżywienia ludności;

- ekonomiczny i fizyczny dostęp do żywności (access to food) - ekonomiczne i fizyczne możliwości pozyskania żywności. Dostęp ekonomiczny do żywności oznacza, że powinna być ona przystępna cenowo, tj. jej pozyskanie nie powinno narażać ludzi na niezaspokojenie innych podstawowych potrzeb, takich jak edukacja czy opieka zdrowotna. Dostęp fizyczny oznacza z kolei, że żywność powinna być dostępna dla wszystkich osób, w tym fizycznie wrażliwych, jak dzieci, osoby starsze czy niepełnosprawne. Dostęp do żywności zależy od kilku czynników, m.in. siły nabywczej, dochodów społeczeństwa, poziomu infrastruktury, $\mathrm{np}$. transportu;

- wykorzystanie żywności (utilisation of food) - zapewnienie jakości zdrowotnej żywności. Oznacza to, że żywność (odpowiednio zbilansowana dieta) powinna dostarczać odpowiednią ilość energii, zawierać niezbędne składniki odżywcze oraz mikro- i makroelementy, a w efekcie w sposób satysfakcjonujący zaspokajać potrzeby fizjologiczne ludzi i umożliwiać im prowadzenie zdrowego i aktywnego życia;

- stabilność dostaw żywności w czasie (stability of food) - gwarancja dostaw żywności bez względu na zmieniające się, nagle lub cyklicznie, warunki otoczenia (np. ekonomiczne, klimatyczne). Stanowi to warunek zapewnienia stałego bezpieczeństwa żywnościowego.

Bezpieczeństwo żywnościowe można rozpatrywać w wymiarze międzynarodowym, narodowym i gospodarstwa narodowego. Wymiary te splatają się, tworząc często zbiór dążeń trudnych do rozdzielenia. Przykładowo w wymiarze międzynarodowym powstają regionalne ugrupowania państw, które stawiają sobie za cel bezpieczeństwo żywnościowe regionu, przy czym zakładają one, że warunkiem bezpieczeństwa regionalnego jest wcześniejsze osiągnięcie bezpieczeństwa narodowego poszczególnych członków ugrupowania. Silna zależność istnieje także między bezpieczeństwem $\mathrm{w}$ wymiarze narodowym $\mathrm{i}$ gospodarstwa domowego. Na przykład bezpieczeństwo żywnościowe gospodarstw domowych o niskich dochodach rozstrzyga się $\mathrm{w}$ wymiarze narodowym na podstawie makrodecyzji państwa. Te same decyzje przesądzają także o innym warunku bezpieczeństwa żywnościowego, tj. o jakości zdrowotnej żywności [Małysz, 2009, s. 95]. 
Zapewnienie bezpieczeństwa żywnościowego w wymiarze międzynarodowym najogólniej wyraża się w dążeniu do usunięcia rażących regionalnych nierówności w zaspokajaniu głodu. Niebagatelną rolę w zmniejszaniu luki żywnościowej w krajach dotkniętych trwałym deficytem żywności odgrywa pomoc żywnościowa, zarówno doraźna, jak i długookresowa. Bezpieczeństwo żywnościowe na poziomie narodowym polega z kolei na zapewnieniu społeczeństwu danego kraju w danym okresie fizycznej i ekonomicznej dostępności żywności, która jest wolna od zanieczyszczeń oraz występuje w optymalnej ilości i w optymalnym zestawie składników pokarmowych. Czynnikami warunkującymi osiągnięcie bezpieczeństwa żywnościowego na poziomie narodowym w dłuższym okresie są w szczególności: ciągłość strumienia podaży produktów żywnościowych, racjonalna gospodarka zasobami naturalnymi, czynniki środowiskowe i klimatyczne, jak również otoczenie administracyjne i społeczno-polityczne [Małysz, 2009, s. 95-106; Kwasek, 2015, s. 15-16]. Z całą pewnością zapewnienie bezpieczeństwa żywnościowego w wymiarze narodowym i ograniczanie regionalnych nierówności odgrywa kluczową rolę w rozwiązywaniu problemów żywnościowych na poziomie globalnym.

\subsection{Ocena bezpieczeństwa żywnościowego Polski na tle państw UE}

Jednym ze wskaźników charakteryzujących bezpieczeństwo żywnościowe danego kraju czy regionu jest publikowany od 2012 r. Światowy Indeks Bezpieczeństwa Żywnościowego (Global Food Security Index - GFSI), liczony dla 113 krajów świata, w tym dla 20 państw Unii Europejskiej. Indeks ten opracowany został przez brytyjski ośrodek badawczy Economist Intelligence Unit i opiera się na modelu uwzględniającym 19 wskaźników, które posłużyły do konstrukcji trzech indeksów cząstkowych, nazwanych następująco: dostępność żywności (affordability), dostęp do żywności (availability) oraz jakość i bezpieczeństwo żywności (quality and safety). Dodatkowo liczony jest indeks pozwalający ocenić zasoby naturalne i zdolność dostosowania sektora rolnictwa do zmian tych zasobów (natural resources \& resilience), skonstruowany z 7 wskaźników [GFSI, 2017, s. 41-44]. Celem analiz dokonywanych na podstawie indeksu GFSI jest ocena, które z badanych krajów są najbardziej, a które najmniej narażone na brak bezpieczeństwa żywnościowego, uwzględniając trzy ww. wymiary bezpieczeństwa, tj. dostępność żywności, dostęp do żywności oraz jakość i bezpieczeństwo żywności. Odrębnie ocenia się zdolność dostosowania sektora rolnictwa do zmian zasobów naturalnych, która pozwala odnieść się do uwarunkowań zapewnienia bezpieczeństwa żywnościowego.

W najnowszym badaniu Światowego Indeksu Bezpieczeństwa Żywnościowego z września 2017 r. Polska znalazła się na 27. pozycji wśród 113 ocenianych krajów świata, a na 15. pozycji wśród badanych 20 państw UE, uzyskując 74,1 pkt na 100 pkt możliwych [GFSI, 2017, s. 9]. Na czele obu list znalazła się Irlandia, 
osiągając 85,6 pkt. Dystans dzielący Polskę od Irlandii pod względem bezpieczeństwa żywnościowego wyniósł zatem aż 11,5 pkt. Wysokie wskaźniki GFSI osiągnęły także takie państwa UE, jak: Wielka Brytania (84,2 pkt), Holandia (82,8 pkt), Niemcy (82,5 pkt) oraz Francja (82,3 pkt). Najniżej ocenione zostało bezpieczeństwo żywnościowe Bułgarii, która z indeksem 62,9 pkt znalazła się na końcu listy ocenianych państw UE, a na 47. pozycji wśród objętych badaniem 113 krajów świata. Jeśli chodzi o subindeks „dostępność żywności”, to Polska w tym rankingu również znalazła się na 15. pozycji wśród państw UE (liderem była Irlandia, a listę zamykała Rumunia). Porównanie dokonane według subindeksu „dostęp do żywności” pozwoliło Polsce usytuować się na 14. pozycji (na czele zestawienia była Wielka Brytania, a na końcu Bułgaria), a według subindeksu ,jakość i bezpieczeństwo żywności" - na 16. pozycji (listę otwierała Portugalia, a zamykała Bułgaria) (tab. 1).

Znacznie lepiej oceniona została zdolność dostosowania sektora rolnictwa Polski do zmian zasobów naturalnych, czyli kolejny dodatkowo analizowany indeks, który uwzględnia m.in. takie zmiany uwarunkowań naturalnych, jak: wzrosty temperatury, susze, powodzie czy sztormy, podtopienia w rolnictwie, erozje gleb i związane z tym niekorzystne zmiany na obszarze łąk i lasów, zagrożenie bioróżnorodności oceanów, uzależnienie od importu żywności, a także zaangażowanie $\mathrm{w}$ ograniczanie negatywnych skutków tych zmian, funkcjonowanie krajowych systemów zarządzania ryzykiem $\mathrm{w}$ rolnictwie oraz umiejętność zarządzania ryzykiem w sytuacji klęsk żywiołowych, a ponadto zmiany demograficzne wynikające ze wzrostu liczby ludności i rozwoju procesu urbanizacji [GFSI, 2017, s. 42]. Zjawiska te, wpływając na rozwój gospodarki żywnościowej, stanowią uwarunkowania wpływające na zapewnienie bezpieczeństwa żywnościowego. Polska w tym rankingu znalazła się na 7. pozycji wśród 113 ocenianych krajów świata i na 6. pozycji wśród 20 państw UE, uzyskując 78,8 pkt na 100 pkt możliwych. Na czele obu list znalazła się Dania, osiągając 82,1 pkt (a zatem wyprzedziła Polskę o zaledwie 3,3 pkt), a najniżej wśród państw UE oceniona została Wielka Brytania $(67,0$ pkt). Wysoka lokata Polski w tym rankingu wynika z jej relatywnie korzystnego geograficznego usytuowania i względnie dogodnych warunków klimatycznych (tab. 1).

Uwzględnianie od niedawna indeksu „zasoby naturalne i dostosowanie sektora rolnictwa" w obliczeniach Światowego Indeksu Bezpieczeństwa Żywnościowego spowodowało uzyskanie skorygowanego indeksu GFSI. W badaniu tego indeksu w 2017 r. Polska znalazła się na 23. pozycji wśród 113 ocenianych krajów świata, a na 15. pozycji wśród badanych 20 państw UE, uzyskując 70,2 pkt na 100 pkt możliwych [GFSI, 2017, s. 14]. Zestawienie otwiera Irlandia, która osiągnęła 79,9 pkt. Dystans dzielący Polskę od Irlandii pod względem bezpieczeństwa żywnościowego wyniósł 9,7 pkt, a zatem był mniejszy niż w przypadku oceny na podstawie 


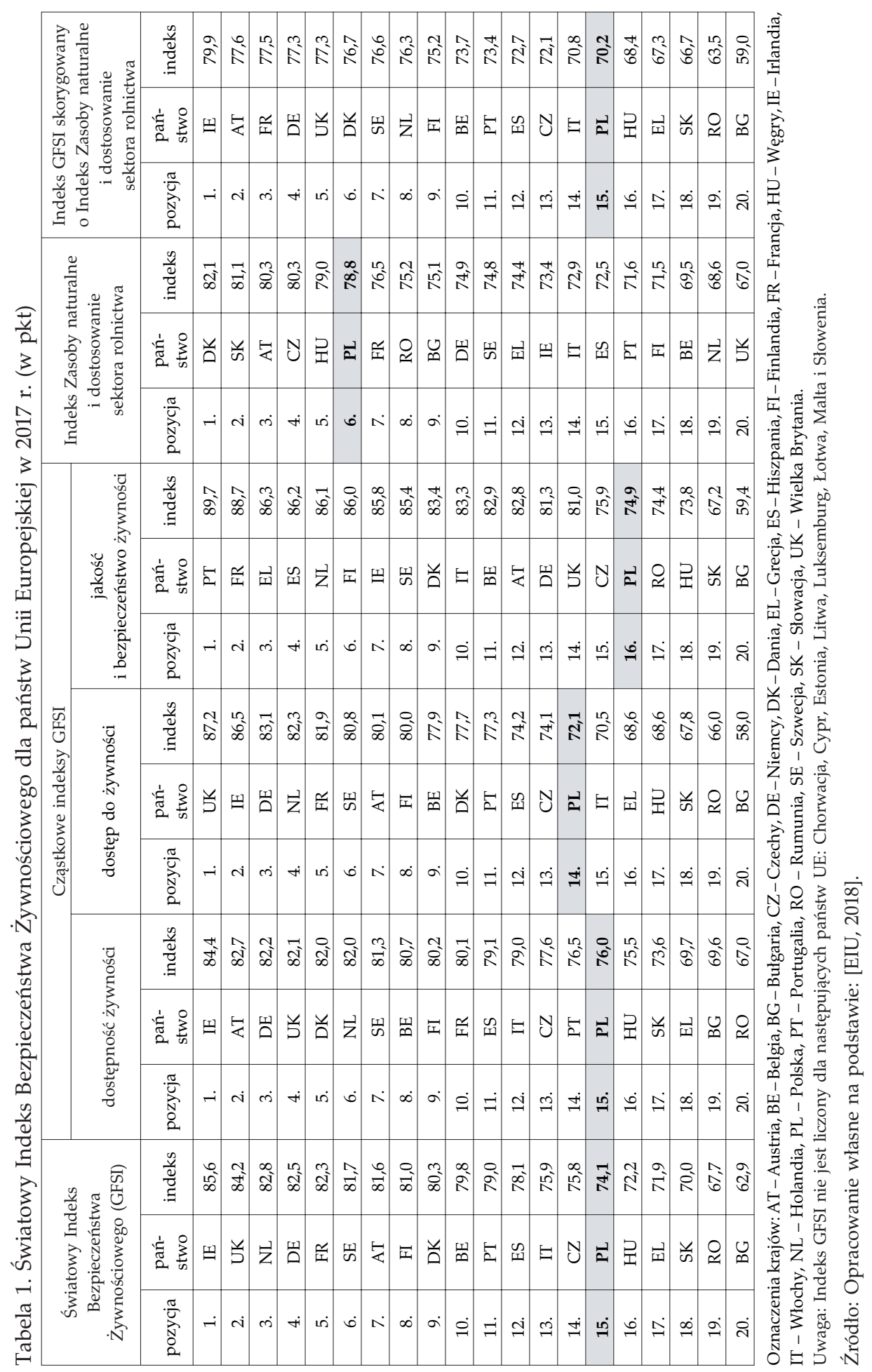


indeksu GFSI, który nie został skorygowany. Wysokie wskaźniki osiągnęły również takie państwa UE, jak: Austria (77,6 pkt), Francja (77,5 pkt), Niemcy (77,3 pkt) oraz Wielka Brytania (77,3 pkt). Najniżej ocenione zostało bezpieczeństwo żywnościowe Bułgarii, która z indeksem 59,0 pkt znalazła się na końcu zestawienia badanych państw UE, a na 42. pozycji wśród ocenianych krajów świata (tab. 1).

W latach 2012-2017 wartość Światowego Indeksu Bezpieczeństwa Żywnościowego w większości badanych państw UE (w czternastu) zwiększyła się najbardziej w Wielkiej Brytanii (o 5,1 pkt), Irlandii (o 3,0 pkt) oraz w Czechach (o 2,2 pkt). Polska również należy do państw, w których bezpieczeństwo żywnościowe w tym okresie się poprawiło, indeks GFSI wzrósł bowiem o 0,8 pkt. Na brak bezpieczeństwa żywnościowego narażone są natomiast takie kraje, jak Grecja i Węgry, w których indeks GFSI obniżył się w analizowanych latach odpowiednio o 3,1 i 1,3 pkt i ukształtował się w $2017 \mathrm{r}$. na relatywnie niskim poziomie (rys. 1).

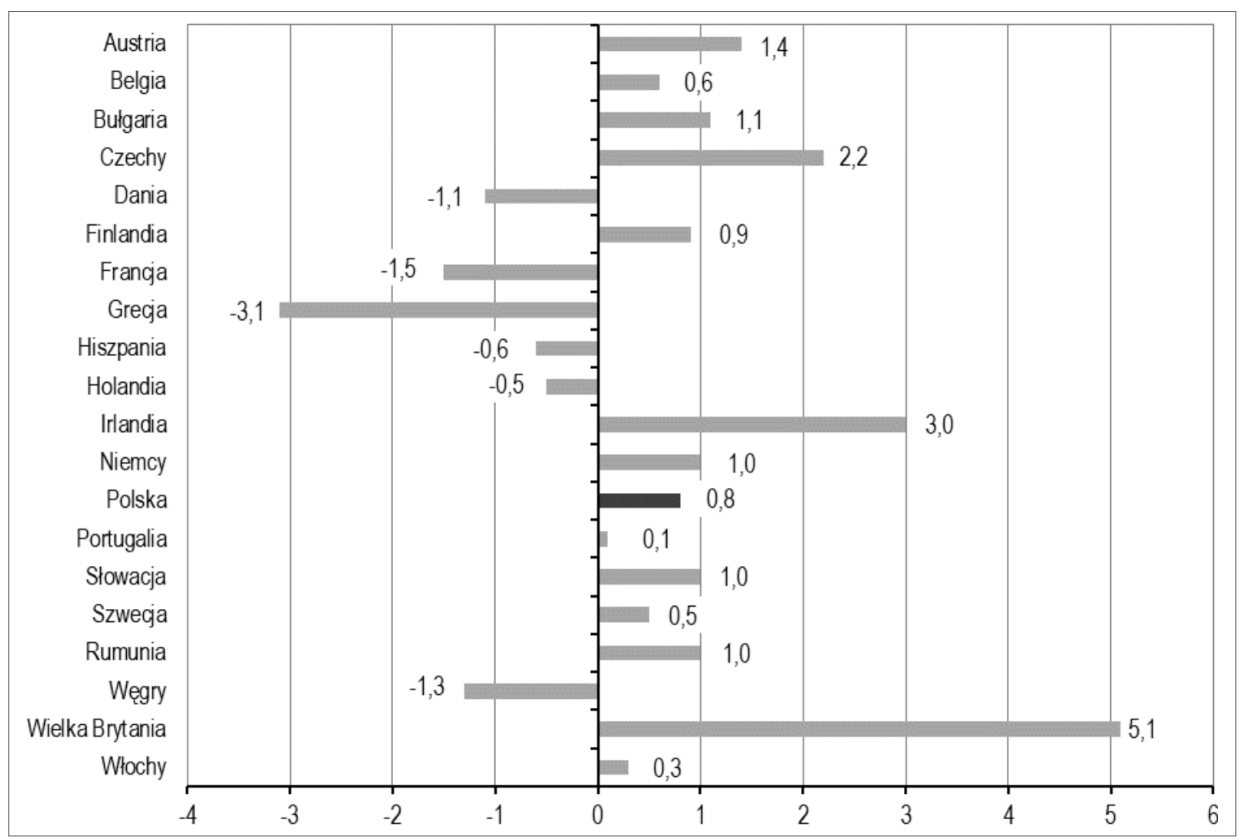

Rysunek 1. Zmiany Światowego Indeksu Bezpieczeństwa Żywnościowego (GFSI) w państwach UE w latach 2012-2017 (w pkt)

Źródło: Opracowanie własne na podstawie: [EIU, 2018].

W przeprowadzonym badaniu określono również czynniki sprzyjające i zagrażające bezpieczeństwu żywnościowemu każdego ocenianego kraju. Do mocnych stron Polski zaliczono jedenaście cech: funkcjonowanie programów wspierających bezpieczeństwo żywnościowe, dostęp rolników do środków finansowych, 
obecność standardów żywieniowych, mieszczący się w światowych normach odsetek ludności żyjącej poniżej granicy ubóstwa, bezpieczeństwo żywności, relatywnie nieduży poziom strat żywności, wystarczającą podaż żywności, zmienność produkcji rolnej, cła importowe na produkty rolne, wysoki udział żywności w wydatkach gospodarstw domowych i dużą zdolność absorpcyjną miast. Za zdecydowanie słabą stronę Polski uznano wartość produktu krajowego brutto przypadającą na jedną osobę [EIU, 2018].

\section{Samowystarczalność żywnościowa}

\subsection{Uwagi teoretyczne}

Jednym z ważniejszych czynników decydujących o bezpieczeństwie żywnościowym jest poziom samowystarczalności żywnościowej (self-sufficiency). Samowystarczalność żywnościowa na poziomie regionalnym, narodowym lub gospodarstwa domowego definiowana jest jako zdolność do zaspokojenia potrzeb żywnościowych wyłącznie z własnej produkcji (rys. 2) [Clapp, 2017, s. 2]. Innymi słowy, w warunkach gospodarki zamkniętej podaż żywności na poziomie regionalnym, narodowym lub indywidualnym powinna pokrywać popyt na żywność odpowiednio regionu, kraju czy gospodarstwa domowego.

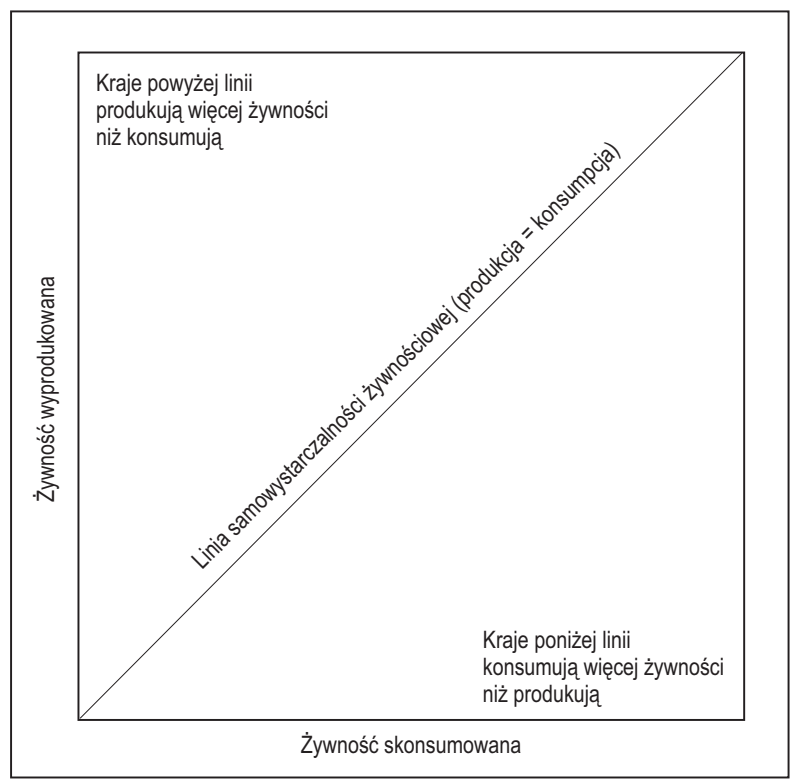

Rysunek 2. Podstawowy schemat samowystarczalności żywnościowej Źródło: Opracowanie własne na podstawie: [Clapp, 2017, s. 2]. 
Wzrost poziomu globalizacji gospodarczej, otwarcie gospodarek na konkurencję zewnętrzną, a także postęp biologiczny i technologiczny sprawiają, że samowystarczalność żywnościowa zmienia obecnie swój charakter, a we współczesnym świecie trudno znaleźć przykłady tendencji autarkicznych. Najogólniej polega to na dążeniu poszczególnych krajów do bilansowania swojego handlu rolno-spożywczego, tj. pokrywania importu produktów rolno-spożywczych eksportem tych produktów. Osiągane w ten sposób saldo zerowe może świadczyć o samowystarczalności żywnościowej. Takie podejście do tego zjawiska oznacza pełną dostępność ekonomiczną i fizyczną żywności na rynku krajowym, niezależnie od źródeł jej pochodzenia, tj. zarówno z produkcji krajowej, jak i z importu [Szczepaniak, 2012a, s. 454-455]. Ocenia się jednak, że dla zapewnienia bezpieczeństwa żywnościowego powinno się wytwarzać w danym kraju czy w ugrupowaniu (np. w UE) co najmniej 70-75\% zapotrzebowania ludności na żywność [Sobiecki, 2007, s. 127-128]. Taka polityka optymalnego poziomu samowystarczalności żywnościowej umożliwia wzbogacenie krajowej oferty asortymentowej żywności o produkty niewytwarzane w kraju (np. z innych stref klimatycznych). Jednocześnie możliwa staje się sprzedaż nadwyżek żywności za granicą. Dzięki takiemu rozwojowi strumieni handlu zagranicznego struktura spożycia żywności staje się bardziej urozmaicona, a potrzeby ludności lepiej zaspokojone.

Mimo iż samowystarczalność żywnościową, oznaczającą pełną dostępność żywności na rynku wewnętrznym, można uzyskiwać różnymi sposobami, podkreśla się potrzebę popierania przez poszczególne kraje i ich ugrupowania własnej produkcji (za pomocą środków polityki interwencyjno-protekcyjnej), a tym samym zwiększanie konkurencyjności własnych producentów żywności. Na tej zasadzie opiera się także w pewnym stopniu Wspólna Polityka Rolna, wspierająca rynek żywności UE oraz stymulująca działania związane z poprawą jakości produktów rolno-spożywczych [Szczepaniak, 2012a, s. 456]. Po jej wprowadzeniu Unia Europejska stała się w ciągu kilku lat regionem niemalże samowystarczalnym żywnościowo.

Wtedy, gdy niektóre kraje są eksporterami netto żywności, a niektóre jej importerami netto, coraz częściej zwraca się uwagę na samowystarczalność żywnościową w skali globalnej. Globalna samowystarczalność żywnościowa zależy nie tylko od poziomu produkcji rolnictwa, rozwoju przetwórstwa spożywczego i swobody handlu, ale również od sfery dystrybucji i różnych uwarunkowań zewnętrznych. Wielu ekspertów uważa, że światowe zasoby produkcji żywności są wystarczające, aby wyżywić ludność całego globu. Głód i niedożywienie, które są problemem w wielu częściach świata, wynikają natomiast z niedoskonałej dystrybucji oraz złych rozwiązań politycznych i niewłaściwych mechanizmów instytucjonalnych. Każdy kraj czy ugrupowanie, realizując politykę optymalnej dla siebie samowystarczalności żywnościowej, przyczynia się do rozwiązania lub 
pogłębienia globalnego problemu żywnościowego. Jednocześnie na społeczeństwach i organizacjach międzynarodowych spoczywa obowiązek zapewnienia odpowiedniego wsparcia krajom najsilniej odczuwającym deficyt żywności [Szczepaniak, 2012a, s. 457].

Do oceny samowystarczalności żywnościowej kraju wykorzystuje się najczęściej trzy metody. Pierwsza z nich polega na analizie wysokości salda handlu zagranicznego produktami rolno-spożywczymi, druga na ocenie relacji eksportu produktów rolno-spożywczych do importu tych produktów [Szczepaniak, 2012b, s. 2], trzecia zaś wykorzystuje wskaźnik stosowany przez Biuro Statystyczne UE Eurostat [Eurostat, 2017]. Stopień samowystarczalności żywnościowej oznacza w tym wypadku stosunek procentowy produkcji krajowej do zużycia krajowego. Zużycie krajowe Eurostat definiuje jako całkowite zużycie produktów rolnych przez ludzi, zwierzęta i przemysł, tj. zużycie na pasze, reprodukcję oraz cele przemysłowe (inne niż na produkcję żywności), przetwórstwo produktów rolnych przez przemysł spożywczy oraz spożycie przez ludność.

Do oceny samowystarczalności żywnościowej Polski, pozostałych państw członkowskich UE oraz całej Unii Europejskiej wybrano wskaźnik samowystarczalności żywnościowej (self-sufficiency ratio - SSR), czyli relację wielkości produkcji podstawowych artykułów rolno-spożywczych do wielkości ich zużycia krajowego (wyrażoną w procentach). Zużycie krajowe w tym przypadku uzyskano przez powiększenie produkcji o import i pomniejszenie jej o eksport. Wskaźnik ten obliczono według następującego wzoru [Clapp, 2017, s. 3]:

$$
S S R=\frac{P}{P+I-E} \times 100
$$

gdzie:

SSR - wskaźnik samowystarczalności,

P - wielkość produkcji krajowej,

I - wielkość importu,

E - wielkość eksportu.

Wskaźnik SSR wyraża stopień pokrycia potrzeb wewnętrznych danego kraju w zakresie podstawowych produktów rolno-spożywczych z produkcji krajowej. Im wyższy poziom wskaźnika samowystarczalności żywnościowej, tym większe szanse na wyżywienie ludności danego kraju z własnej produkcji.

W obliczeniach wskaźników SSR wykorzystano niepublikowane dane Organizacji Narodów Zjednoczonych ds. Wyżywienia i Rolnictwa (FAO). W pracy analizowano najnowsze dostępne informacje, tj. dane za rok 2013. 


\subsection{Ocena samowystarczalności żywnościowej Polski na tle państw UE}

W niniejszym badaniu przeanalizowano wskaźniki samowystarczalności żywnościowej dla Unii Europejskiej i wszystkich jej państw członkowskich (w tym Polski) w zakresie pięciu podstawowych grup produktów rolno-spożywczych, tj. zbóż, warzyw, owoców, mięsa i mleka (tab. 2). Dodatkowo oceniono samowystarczalność żywnościową Polski na tle UE w zakresie takich produktów, jak: rośliny cukrowe, cukier, rośliny oleiste, oleje roślinne, napoje alkoholowe, masło, jaja oraz ryby i owoce morza [FAO, 2018].

Analiza samowystarczalności żywnościowej w zakresie podstawowych produktów pochodzenia roślinnego wykazała, że w 2013 r. UE była samowystarczalna, jeśli chodzi o zboża $(109,8 \%)$ i warzywa $(101,0 \%)$, a tylko w owocach wskaźnik SRR kształtował się poniżej progu samowystarczalności (76,2\%). W zakresie produktów pochodzenia zwierzęcego, tj. mięsa i mleka, UE była w pełni samowystarczalna - wskaźnik SRR wyniósł odpowiednio 105,8\% i 111,1\% (tab. 2).

Na rynku zbóż najwyższe wskaźniki samowystarczalności spośród państw UE osiągnęly: Bułgaria (345,5\%), Litwa $(220,1 \%)$, Łotwa (199,5\%) oraz Francja (196,7\%). Produkcja zbóż w Polsce również przekraczała ich zużycie krajowe (o 11,1\%). Krajami, które w największym stopniu nie były pod tym względem samowystarczalne, okazały się: Malta (6,7\%), Cypr $(9,7 \%)$, Holandia $(15,8 \%)$ oraz Portugalia $(27,7 \%)$. Jeśli chodzi o warzywa, najwyższy wskaźnik SRR osiągnęła Holandia $(284,0 \%)$ i Hiszpania $(184,9 \%)$. W Polsce wyniósł on 113,7\%. Większość państw UE nie była samowystarczalna żywnościowo w zakresie warzyw, co najbardziej dotyczyło takich krajów, jak: Luksemburg $(3,4 \%)$, Czechy $(23,6 \%)$ oraz Słowacja $(24,1 \%)$. Na rynku owoców najwyższymi wskaźnikami samowystarczalności spośród państw UE charakteryzowały się: Grecja (160,4\%), Hiszpania (160,2\%) oraz Cypr (152,0\%). W Polsce produkcja owoców była wyższa od ich zużycia krajowego o $38,2 \%$, a zatem wskaźnik ten również należał do relatywnie wysokich. Podobnie jak w zakresie warzyw, także w zakresie owoców większość krajów UE nie była samowystarczalna żywnościowo. Wskaźnik SRR był najniższy w takich krajach, jak: Finlandia (3,9\%), Szwecja (4,8\%), Wielka Brytania (4,8\%), Irlandia $(6,4 \%)$ oraz Estonia $(7,7 \%)$.

Jeśli chodzi o mięso, najwyższy poziom samowystarczalności osiągnęły następujące państwa UE: Dania (303,7\%), Irlandia (228,8\%), Belgia (226,7\%) oraz Holandia $(175,6 \%)$. Relatywnie wysoki wskaźnik SRR charakteryzował również polski rynek mięsa $(132,3 \%)$. Nie były natomiast samowystarczalne żywnościowo w tym zakresie przede wszystkim: Malta (31,7\%) i Luksemburg (39,6\%). Na rynku mleka produkcja w największym stopniu przewyższała zużycie krajowe w: Danii $(213,5 \%)$, Irlandii (201,9\%), Luksemburgu $(188,1 \%)$, Holandii $(181,5 \%)$ oraz na Łotwie $(177,3 \%)$. W Polsce wskaźnik SRR wyniósł 117,5\%. Krajem, który w największym stopniu nie był pod tym względem samowystarczalny, okazała się Malta $(41,1 \%)$. 
Tabela 2. Wskaźniki samowystarczalności żywnościowej (SSR) w zakresie podstawowych produktów rolno-spożywczych w państwach Unii Europejskiej w 2013 r. (w \%)

\begin{tabular}{|l|r|r|r|r|r|}
\hline \multicolumn{1}{|c|}{ Wyszczególnienie } & Zboża & Warzywa & Owoce & Mięso & Mleko \\
\hline Austria & 85,6 & 60,3 & 58,5 & 115,5 & 129,2 \\
\hline Belgia & 39,8 & 129,4 & 32,3 & 226,7 & 100,1 \\
\hline Bułgaria & 345,5 & 78,6 & 67,3 & 54,1 & 91,9 \\
\hline Chorwacja & 113,3 & 59,4 & 70,6 & 67,4 & 72,7 \\
\hline Cypr & 9,7 & 81,6 & 152,0 & 77,4 & 93,6 \\
\hline Czechy & 140,2 & 23,6 & 31,9 & 64,6 & 123,2 \\
\hline Dania & 108,6 & 46,1 & 9,3 & 303,7 & 213,5 \\
\hline Estonia & 150,9 & 52,7 & 7,7 & 81,3 & 164,3 \\
\hline Finlandia & 112,3 & 53,1 & 3,9 & 91,6 & 96,0 \\
\hline Francja & 196,7 & 72,9 & 57,9 & 97,8 & 136,8 \\
\hline Grecja & 80,9 & 111,5 & 160,4 & 49,9 & 63,2 \\
\hline Hiszpania & 74,8 & 184,9 & 160,2 & 125,4 & 71,4 \\
\hline Holandia & 15,8 & 284,0 & 21,7 & 175,6 & 181,5 \\
\hline Irlandia & 62,5 & 46,2 & 6,4 & 228,8 & 201,9 \\
\hline Litwa & 220,1 & 70,8 & 38,5 & 92,4 & 134,9 \\
\hline Luksemburg & 73,3 & 3,4 & 12,9 & 39,6 & 188,1 \\
\hline Lotwa & 199,5 & 62,4 & 18,3 & 64,3 & 177,3 \\
\hline Malta & 6,7 & 80,2 & 23,1 & 31,7 & 41,1 \\
\hline Niemcy & 113,4 & 39,8 & 27,3 & 114,2 & 130,6 \\
\hline Polska & $\mathbf{1 1 1 , 1}$ & $\mathbf{1 1 3 , 7}$ & $\mathbf{1 3 8 , 2}$ & $\mathbf{1 3 2 , 3}$ & $\mathbf{1 1 7 , 5}$ \\
\hline Portugalia & 27,7 & 134,8 & 77,7 & 76,0 & 80,0 \\
\hline Rumunia & 156,9 & 92,5 & 82,3 & 83,4 & 93,1 \\
\hline Słowacja & 142,2 & 24,1 & 29,9 & 49,5 & 96,4 \\
\hline Słowenia & 57,3 & 37,1 & 62,1 & 81,2 & 111,4 \\
\hline Szwecja & 109,9 & 38,1 & 4,0 & 62,9 & 86,8 \\
\hline Węgry & 158,0 & 148,9 & 112,1 & 125,0 & 104,4 \\
\hline Wielka Brytania & 80,8 & 38,4 & 4,8 & 69,3 & 82,0 \\
\hline Włochy & $\mathbf{7 2 , 0}$ & 142,3 & 109,9 & 79,3 & 69,1 \\
\hline Unia Europejska & & $\mathbf{1 0 1 , 0}$ & $\mathbf{7 6 , 2}$ & $\mathbf{1 0 5 , 8}$ & $\mathbf{1 1 1 , 1}$ \\
\hline (09, & & & \\
\hline
\end{tabular}

Uwaga: Mleko łącznie z przetworami mlecznymi w ekwiwalencie mleka, bez masła.

Źródło: Obliczenia własne na podstawie: [FAO, 2018].

W zakresie pozostałych wybranych produktów rolno-spożywczych Polska nie była samowystarczalna żywnościowo tylko w przypadku olejów roślinnych (SRR $=80,6 \%)$ oraz ryb i owoców morza $(52,5 \%)$. Wynikało to z naturalnych uwarunkowań rozwoju tych rynków, tj. dużego udziału importu w ich zaopatrzeniu (produkty należące do tych grup są wytwarzane w Polsce tylko w niektórych asortymentach lub na niewielką skalę). Na poziomie całej Unii Europejskiej niski 
poziom samowystarczalności żywnościowej odnotowano nie tylko w zakresie ryb i owoców morza oraz olejów roślinnych, ale również roślin oleistych, cukru i roślin cukrowych. Zadowalające wskaźniki SRR cechowały tylko rynek napojów alkoholowych, masła i jaj (tab. 3).

Tabela 3. Wskaźniki samowystarczalności żywnościowej (SSR) w zakresie wybranych produktów rolno-spożywczych w Polsce i Unii Europejskiej w 2013 r. (w \%)

\begin{tabular}{|l|c|c|c|c|c|c|c|c|}
\hline $\begin{array}{c}\text { Wyszcze- } \\
\text { gólnienie }\end{array}$ & $\begin{array}{c}\text { Rośliny } \\
\text { cukrowe }\end{array}$ & Cukier & $\begin{array}{c}\text { Rośliny } \\
\text { oleiste }\end{array}$ & $\begin{array}{c}\text { Oleje } \\
\text { roślinne }\end{array}$ & $\begin{array}{c}\text { Napoje } \\
\text { alkoho- } \\
\text { lowe }\end{array}$ & Masło & Jaja & $\begin{array}{c}\text { Ryby } \\
\text { i owoce } \\
\text { morza }\end{array}$ \\
\hline Polska & 100,0 & 111,6 & 113,1 & 80,6 & 101,8 & 111,8 & 163,2 & 52,5 \\
\hline $\begin{array}{l}\text { Unia } \\
\text { Europejska }\end{array}$ & 99,9 & 84,6 & 58,8 & 68,6 & 108,1 & 100,6 & 102,0 & 49,1 \\
\hline
\end{tabular}

Źródło: Obliczenia własne na podstawie: [FAO, 2018].

Reasumując, można stwierdzić, że Polska jest samowystarczalna żywnościowo w zakresie podstawowych i wielu innych produktów rolno-spożywczych. Unia Europejska jako całość również w większości przypadków charakteryzuje się produkcją wyższą od zużycia wewnętrznego. Potwierdzają to wcześniejsze badania przeprowadzone m.in. przez Chechelskiego i in. [Chechelski, Kwasek, Mroczek, 2016, s. 165-182], Obiedzińską [Obiedzińska, 2016, s. 130-133] czy Szczepaniak [Szczepaniak, 2012a, s. 454-464]. Dokonana analiza udowadnia jednak, że samowystarczalność żywnościowa państw członkowskich UE w zakresie poszczególnych grup produktów rolno-spożywczych jest mocno zróżnicowana.

\section{Podsumowanie}

Bezpieczeństwo żywnościowe ma fundamentalne znaczenie dla zdrowia i jakości życia człowieka. Na bezpieczeństwo żywnościowe składają się cztery wymiary: fizyczna dostępność żywności, ekonomiczny i fizyczny dostęp do żywności, jakość zdrowotna żywności oraz stabilność dostaw żywności w czasie. Poziom wyżywienia społeczeństwa zależy przede wszystkim od fizycznej dostępności żywności i ekonomicznego dostępu do żywności. Produkcja rolnictwa, przemysłu spożywczego, import, eksport oraz zapasy surowców i produktów spożywczych decydują o fizycznej dostępności żywności. Dochody ludności, ceny żywności oraz pozostałych dóbr i usług determinują natomiast ekonomiczny dostęp do żywności. Niezwykle istotna jest również jakość zdrowotna żywności, która stanowi nieodzowny warunek sprawności fizycznej i intelektualnej człowieka. Znaczenie zapewnienia stabilności w czasie tych trzech warunków bezpieczeństwa żywnościowego jest oczywiste. 
Na polskim rynku dostępna jest większość produktów żywnościowych, które warunkują zdrowe odżywianie się, innymi słowy produktów niezbędnych do prawidłowej egzystencji człowieka. Świadczą o tym wskaźniki samowystarczalności żywnościowej kraju. Polska osiągnęła samowystarczalność żywnościową, mierzoną jako relacja produkcji do zużycia krajowego, w zakresie m.in. mięsa, jaj, mleka, owoców, warzyw, roślin oleistych, zbóż, masła i cukru. Na tle pozostałych państw Unii Europejskiej sytuacja Polski pod tym względem przedstawia się korzystnie. Wynika to z faktu, że Polska była i jest jednym z ważniejszych producentów żywności w UE. Pomiędzy poszczególnymi krajami występuje jednak znaczne zróżnicowanie samowystarczalności żywnościowej.

Poziom samowystarczalności żywnościowej jako jeden z czynników decydujących o bezpieczeństwie żywnościowym umożliwił ocenę zróżnicowania bezpieczeństwa żywnościowego w Unii Europejskiej, a ściślej mówiąc ocenę, które z badanych krajów są najbardziej, a które najmniej narażone na brak bezpieczeństwa żywnościowego. Przeprowadzona analiza wykazała, że Unia Europejska jako całość zapewnia bezpieczeństwo żywnościowe swoim obywatelom, ale jednocześnie z badań tych wynika duże zróżnicowanie sytuacji w poszczególnych państwach. Polska zajęła 15. miejsce wśród 20 państw UE ocenianych na podstawie Światowego Indeksu Bezpieczeństwa Żywnościowego. Ta dość odległa lokata dowodzi potrzeby podejmowania w kraju działań, w tym inicjatyw o charakterze informacyjno-edukacyjnym, na rzecz zapewnienia i poprawy bezpieczeństwa żywnościowego.

\section{Źródła finansowania}

Badania zostały sfinansowane ze środków Programu Wieloletniego pt. „Rolnictwo polskie i UE 2020+. Wyzwania, szanse, zagrożenia, propozycje”, realizowanego w Instytucie Ekonomiki Rolnictwa i Gospodarki Żywnościowej - Państwowym Instytucie Badawczym w latach 2015-2019 (Umowa nr Fgr. 4302-14/2015/um z dnia 27.05.2015 r. pomiędzy Ministerstwem Rolnictwa i Rozwoju Wsi a IERiGŻ-PIB).

\section{Bibliografia}

Chechelski P., Kwasek M., Mroczek R., 2016, Zmiany w otoczeniu przemystu spożywczego zachodzace pod wptywem globalizacji. Wybrane problemy, Instytut Ekonomiki Rolnictwa i Gospodarki Żywnościowej - Państwowy Instytut Badawczy, Warszawa.

Clapp J., 2017, Food self-sufficiency and International trade. A false dichotomy?, The State of Agricultural Commodity Markets IN DEPTH 2015-16, FAO, http://www.fao.org/3/a-i5222e.pdf [dostęp: 08.01.2018].

EIU, 2018, The Economist Intelligence Unit Limited, http://foodsecurityindex.eiu.com [dostęp: 09.01.2018]. 
European Commission, 2009, Food security. Understanding and meeting the challenge of poverty, Publications Office of the European Union, Brussels, Belgium.

Eurostat, 2017, http://epp.eurostat.ec.europa.eu/portal/page/portal/eurostat/home [dostęp: 05.09.2017].

FAO, 2009, The State of Food Insecurity in the World 2009. Economic crisis - impacts and lesson learned, FAO, Rome.

FAO, 2015, The State of Food Insecurity in the World. Meeting the 2015 international hunger targets. Taking stock of uneven progress, FAO, IFAD, WFP, Rome.

FAO, 2018, http://www.fao.org/faostat/en/\#data/FSB [dostęp: 16.01.2018].

GFSI, 2017, Global Food Security Index 2017. Measuring Food Security and the impact of resource risks, The Economist Intelligence Unit Limited.

Kowalczyk S., 2016, Bezpieczeństwo i jakość żywności, Wydawnictwo Naukowe PWN, Warszawa.

Kwasek M. (red.), 2015, Z badań nad rolnictwem społecznie zrównoważonym (33). Analiza bezpieczeństwa żywnościowego Polski, Instytut Ekonomiki Rolnictwa i Gospodarki Żywnościowej - Państwowy Instytut Badawczy, Warszawa.

Małysz J., 2009, Ekonomiczna interpretacja bezpieczeństwa żywnościowego, [w:] Bezpieczeństwo żywności w erze globalizacji, red. S. Kowalczyk, Szkoła Główna Handlowa, Warszawa.

Obiedzińska A., 2016, Wybrane aspekty zapewnienia bezpieczeństwa żywnościowego w Unii Europejskiej, Studia BAS, nr 4.

ONZ, 1948, Powszechna Deklaracja Praw Człowieka, http://www.unesco.pl/fileadmin/ user_upload/pdf/Powszechna_Deklaracja_Praw_Czlowieka.pdf [dostęp: 09.01.2018].

Sobiecki R., 2007, Globalizacja ekonomiczna a zmiana uwarunkowań produkcji rolniczej, Realia i co dalej, nr 2.

Szczepaniak I., 2012a, Ocena poziomu samowystarczalności żywnościowej Polski w warunkach integracji i globalizacji gospodarczej, [w:] Polityka ekonomiczna, red. J. Sokołowski, M. Sosnowski, A. Żabiński, Prace Naukowe Uniwersytetu Ekonomicznego we Wrocławiu, nr 246, Wrocław.

Szczepaniak I., 2012b, Samowystarczalność żywnościowa Polski, Przemysł Spożywczy, nr 2.

I. Szczepaniak (『) Iwona.Szczepaniak@ierigz.waw.pl

Instytut Ekonomiki Rolnictwa i Gospodarki Żywnościowej - Państwowy Instytut Badawczy, ul. Świętokrzyska 20, 00-002 Warszawa, Polska 